DOI 10.31558/2307-2318.2019.4.15

УДК 339.97:338.001.36

Слоква М.Г., кандидат економічних наук, доцент кафедри зовнішньоекономічної діяльності підприємства Київського національного торговельно-економічного університету

П'янкова О. В., кандидат економічних наук, доцент кафедри зовнішньоекономічної діяльності підприємства Київського національного торговельно-економічного університету

\title{
ЕКОЛОГІЗАЦІЯ УПРАВЛІННЯ У КОНТЕКСТІ СУЧАСНИХ ГЛОБАЛЬНИХ ЕНЕРГЕТИЧНИХ ТА ЕКОЛОГІЧНИХ ТРЕНДІВ
}

Статтю присвячено аналізу глобальних енергетичних та екологічних трендів як чинників посилення тенденцій екологізації управління. За результатами проведеного аналізу встановлено, що інтенсивний розвиток світової економіки у другій половині 20го сторіччя спричинив стрімке зростання попиту на енергетичні ресурси. Значна активізація споживання первинної енергії відмічається з початку 2000-х років, що більшою мірою забезпечувалося зростанням попиту у країнах АзійськоТихоокеанського регіону. Зростання споживання первинної енергії відмічається за всіма видами енергетичних ресурсів. За період 1990-2018 років виявлено скорочення енергоємності глобальної економіки, хоча останнім часом відмічено певне його уповільнення. Зростання споживання енергетичних ресурсів обумовило відповідне збільшення викидів двоокису вуглецю i, як результат, виникнення низки екологічний проблем. 3 початку 2000-х років вельми активно зростають викиди двоокису вуглецю у країнах Азійсько-Тихоокеанського регіону. Інтенсивність викидів двоокису вуглецю у світі протягом останніх десятирічь поступово знижується. Незважаючи на певні позитивні зміни, економіка України характеризується найменшою у світі енергетичною ефективністю та найбільшою інтенсивністю викидів, що затребує впровадження більш дієвих заходів екологічної політики.

Ключові слова: споживання первинної енергії, енергоємність економіки, енергетична ефективність економіки, викиди двоокису вуглецю, інтенсивність викидів двоокису вуглецю, глобальні енергетичні тренди, глобальні екологічні тренди, екологізація управління.

Рис. - 7, Таб. - 2, Літ. - 26.

\section{Слоква М.Г., Пьянкова О.В.}

ЭКОЛОГИЗАЦИЯ УПРАВЛЕНИЯ В КОНТЕКСТЕ СОВРЕМЕННЫХ ГЛОБАЛЬНЫХ ЭНЕРГЕТИЧЕСКИХ И ЭКОЛОГИЧЕСКИХ ТРЕНДОВ

Статья посвящена анализу глобальных энергетических и экологических трендов как факторов усиления тенденций экологизации управления. По результатам проведенного анализа установлено, что интенсивное развитие мировой экономики во второй половине 20-го столетия обусловило стремительный рост спроса на энергетические ресурсы. Значительная активизация потребления первичной энергии отмечается с начала 2000 -х годов, что в большей степени обеспечивалось ростом спроса в странах Азиатско-Тихоокеанского региона. Рост потребления первичной энергии отмечается по всем видам энергетических ресурсов. За период 1990-2018 годов установлено сокращение энергоемкости глобальной экономики, хотя в последнее время отмечено некоторое его замедление. Рост потребления энергетических ресурсов 
обусловил соответствующее увеличение выбросов диоксида углерода и, как результат, возникновение ряда экологический проблем. С начала 2000-х годов весьма активно рост выбросов диоксида углерода протекает в странах Азиатско-Тихоокеанского региона. Интенсивность выбросов диоксида углерода в мире в течение последних десятилетий постепенно снижается. Несмотря на определенные позитивные изменения, экономика Украины характеризуется наименьшей в мире энергетической эффективностью и наибольшей интенсивностью выбросов, что требует внедрения более действенных мероприятий экологической политики.

Ключевые слова: потребление первичной энергии, энергоемкость экономики, энергетическая эффективность экономики, выбросы диоксида углерода, интенсивность выбросов диоксида углерода, глобальные энергетические тренды, глобальные экологические тренды, экологизация управления.

\section{Slokva M., Piankova O. \\ ENVIRONMENTAL MANAGEMENT IN THE CONTEXT OF CONTEMPORARY GLOBAL ENERGY AND ENVIRONMENTAL TRENDS}

The article is devoted to the analysis of global energy and environmental trends as factors of strengthening the trends in greening management. According to the results of the analysis, it was found that the intensive development of the world economy in the second half of the 20th century led to a rapid increase in demand for energy resources. Significant intensification of primary energy consumption has been observed since the beginning of the 2000s, which was largely ensured by increased demand in the countries of the Asia-Pacific region. Primary energy consumption growth is noted for all types of energy resources. In the period 1990-2018, a reduction in the energy intensity of the global economy has been observed, although some of its slowdown has recently been noted. The increase in energy consumption has led to a corresponding increase in carbon dioxide emissions and, as a result, a number of environmental problems. Since the early 2000s, carbon dioxide emissions have been increasing rapidly in the countries of the Asia-Pacific region. The intensity of carbon dioxide emissions in the world over the past decades has been gradually decreasing. Despite certain positive changes, the Ukrainian economy is characterized by the world's lowest energy efficiency and the highest emission intensity, which requires the implementation of more effective environmental policy measures.

Keywords: primary energy consumption, energy intensity of the economy, energy efficiency of the economy, carbon dioxide emissions, carbon dioxide emissions intensity, global energy trends, global environmental trends, greening management.

Постановка проблеми. 3 кожним роком у світі відмічається посилення антропогенного і техногенного навантаження на навколишнє природне середовище. Протягом останніх десятирічь світова спільнота активізувалася у прийнятті заходів із запобігання даному явищу. Прийняття та реалізація Кіотського протоколу, підписання Паризьких угод мають за мету зниження негативних екологічних наслідків господарювання людини. Проте, незважаючи на здійснені зусилля, проблема забруднення навколишнього природного середовища продовжує загострюватися.

Паливно-енергетичний комплекс $є$ провідним сектором економіки, оскільки забезпечує можливості функціонування інших галузей шляхом задоволення їх потреб у відповідних енергетичних ресурсах. Разом з тим, будучи визначальним чинником суспільного відтворення, дана галузь також відіграє найпомітнішу роль у загостренні 
світових екологічних проблем, оскільки на неї припадає значна питома частка у загальному обсязі забруднення, зокрема, викидів двоокису вуглецю. Аналіз тенденцій розвитку енергетичного сектору економіки та екологічної складової, їх співставлення та визначення відповідності вбачається затребуваним з позиції встановлення ключових факторів виникнення та загострення глобальних екологічних проблем, з'ясування відповідності очікуваних наслідків реалізації глобальної екологічної політики та отриманих результатів, окреслення пріоритетів в управлінні суб'єктами господарювання, зокрема, першочергове урахування екологічних чинників при визначенні відповідних заходів. Дані обставини обумовили необхідність розгляду означених питань та вибір теми наукової статті.

Аналіз останніх досліджень і публікацій 3 проблеми, що розглядається. Останнім часом стрімко збільшується кількість наукових робіт з екологічної тематики як у вітчизняних, так і у зарубіжних наукових колах. Серед них варто відзначити численні роботи, присвячені визначенню взаємозв'язку та взаємозалежностей між економічним розвитком та екологічною складовою, зокрема таких вітчизняних учених, як: В. Власенко [1], 3. Герасимчук [2], Л. Гринів [3], В. Грищенко [4], Б. Данилишин [5], В. Дергачова [6], С. Дорогунцов [7], А. Жихарєва [8], Р. Корпан [9], Я. Кульчицький [10], А. Ральчук [7], Т. Туниця [11], А. Цибуляк [12] та багатьох інших. Не менш популярною дана тематика є серед американських та європейських науковців [13-20].

Більше того у 2018 році й Нобелівську премію з економіки було вручено професору Єльського університету Уїльяму Д. Нордхаусу [21] саме за опрацювання проблеми впливу кліматичних змін на світову економіку, дослідження якої він розпочав ще у 70-х роках минулого сторіччя. У своїй роботі вчений обгрунтував, що найбільш ефективним способом контролю глобального потепління $є$ прогресивна загальносвітова система оподаткування викидів парникових газів [22]. При цьому така система має діяти в усіх країнах, які повинні будуть фінансово компенсувати викиди вуглецю в атмосферу.

Незважаючи на численні наукові дослідження проблеми виявлення взаємозалежностей між економічним розвитком та екологічною ситуацією, розробку та впровадження заходів екологічної політики, спрямованих на зниження екологічного навантаження на довкілля, проте питання встановлення дієвості цих заходів та виокремлення чинників, які перешкоджають їх результативності, залишаються не повною мірою висвітленими, що обумовлює необхідність подальшого наукового пошуку.

Метою статті $є$ аналіз сучасних глобальних енергетичних та екологічних трендів, встановлення їх відповідності з позиції необхідності визначення дієвості застосовуваних заходів екологічної політики, ідентифікація чинників посилення світових тенденцій екологізації управління.

Виклад основного матеріалу. Стрімке нарощування обсягів світового виробництва у другій половині 20-го сторіччя обумовило зростання попиту на ресурси, помітне місце серед яких займає первинна енергія. Споживання первинної енергії у світі безупинно зростає, так у 2018 р. цей показник дорівнював 13864,9 млн т у нафтовому еквіваленті (далі - н.е.), що у 3,7 рази більше рівня 1965 р., коли він становив 3701,5 млн т н. е. (рис. 1). Зростання споживання первинної енергії у світі спостерігається протягом усього досліджуваного періоду, періодично посилюючись у відповідні періоди.

Неоднозначна тенденція у споживанні енергії відмічається за країнами світу. Найбільш повільне зростання обсягів споживання протягом останніх п'ятдесяти років відмічається по країнах СС - на 68,4\%, більше того, періодично для них було характерно, навіть, скорочення обсягів використовуваної первинної енергії, зокрема, й у 2018 році. 
Споживання первинної енергії за країнами-членами Організації економічного співробітництва та розвитку (далі - ОЕСР) за досліджуваний період зросло у 2,2 рази 3 2610 млн т н. е. у 1965 році до 5669 млн т н. е. у 2018 році. Найбільш інтенсивне зростання споживання відмічається по країнах, що не є членами ОЕСР - більше ніж у 7,5 рази, з 1091,5 млн т н. е. у 1965 р. до 8195,9 млн т н.е. у 2018 р. Варто зазначити, що зростання попиту на енергію по даній групі країн особливо прискорилося, починаючи 3 2000 років, Так, тільки за перші 18 років XXI сторіччя по країнах, що не є членами ОЕСР, споживання зросло більше ніж у 2 рази, у той час, як по країнах-членах ОЕСР зростання відмічається на рівні 4,6\%, а по країнах ЄС взагалі спостерігається скорочення споживання на 3,5\%. Вищеописані тенденції спричинили інтенсифікацію загальносвітового споживання первинної енергії у той же період. Так, зростання обсягів спожитої у світі первинної енергії з 2000 по 2018 роки відбулося майже у 1,5 рази, у той час як з 1965 по 2000 роки даний показник виріс у 2,5 рази. У результаті у 2018 році $59,1 \%$ спожитої у світі первинної енергії припадало на країни, що не є членами ОЕСР, 40,9\% - на країни-члени ОЕСР, з них на країни $Є С-12,2 \%$. У той час як у 1965 році на країни, що не є членами ОЕСР, припадало лише 29,5\% світового споживання первинної енергії, на країни-члени ОЕСР - 70,5\%, 3 них 27,1\% - на країни, що за теперішнього часу входять до ЄС. Отже, протягом останніх п'ятдесяти років відбулися суттєві зміни у питомій частці економічно розвинутих країн у споживанні первинної енергії у світі. Як видно провідні позиції за теперішнього часу займають країни, що не є членами ОЕСР, які споживають майже у 1,5 рази більше ніж країни першої групи.

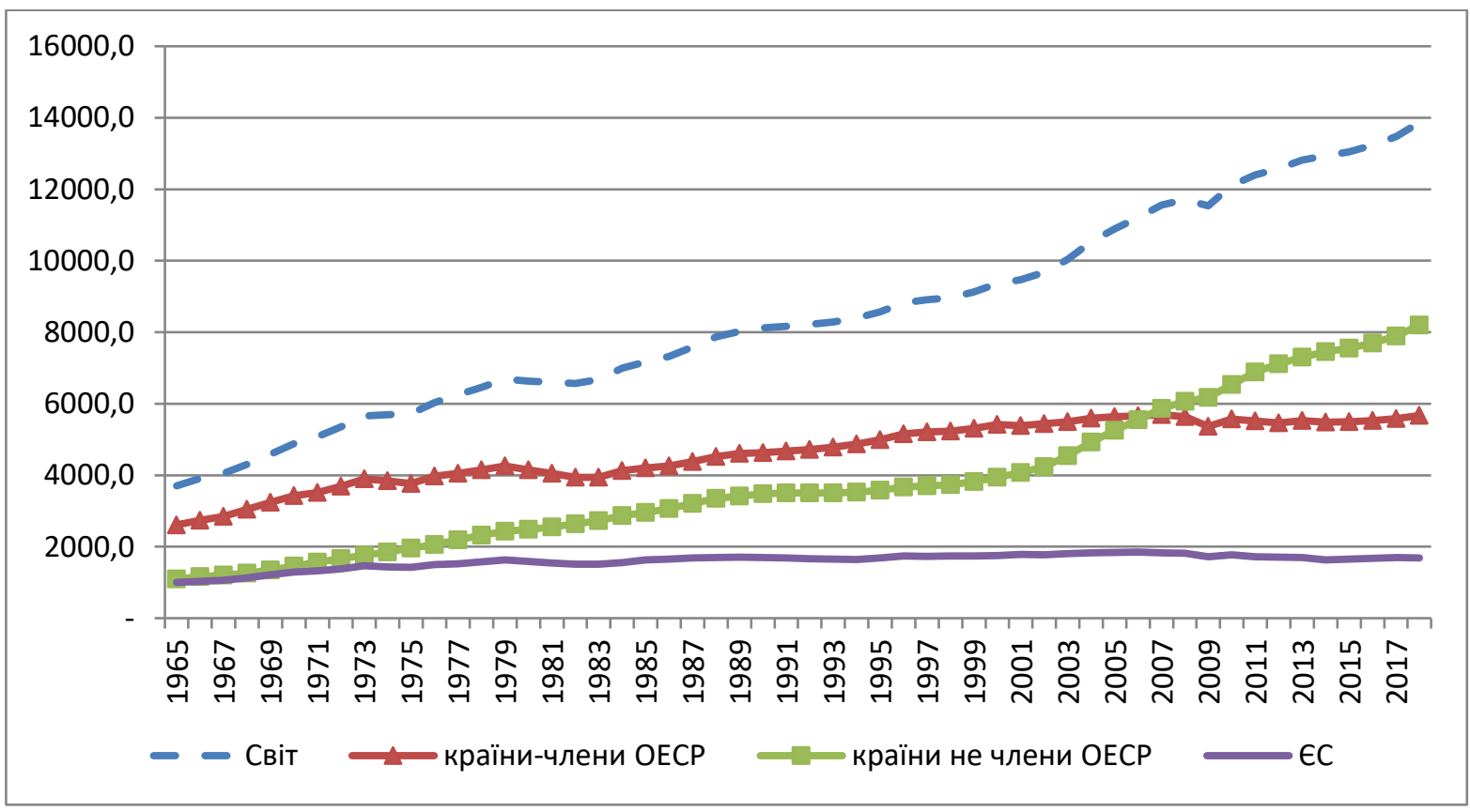

\section{Рисунок 1 - Динаміка споживання первинної енергії у світі у 1965-2018 рр.* *складено за даними BP Statistical Review of World Energy June 2019 [23]}

Результати аналізу географічної структури світового споживання первинної енергії за останні п’ятдесят років свідчать про суттєві зміни у попиті за регіонами світу (рис. 2). Так, якщо у 60-х роках провідними споживачами енергії у світі виступали країни 
Північної Америки, а на другому місці посідали країни Європи, то наприкінці 20-го століття відмічаються певні зміни у ролі певних регіонів за цим показником.

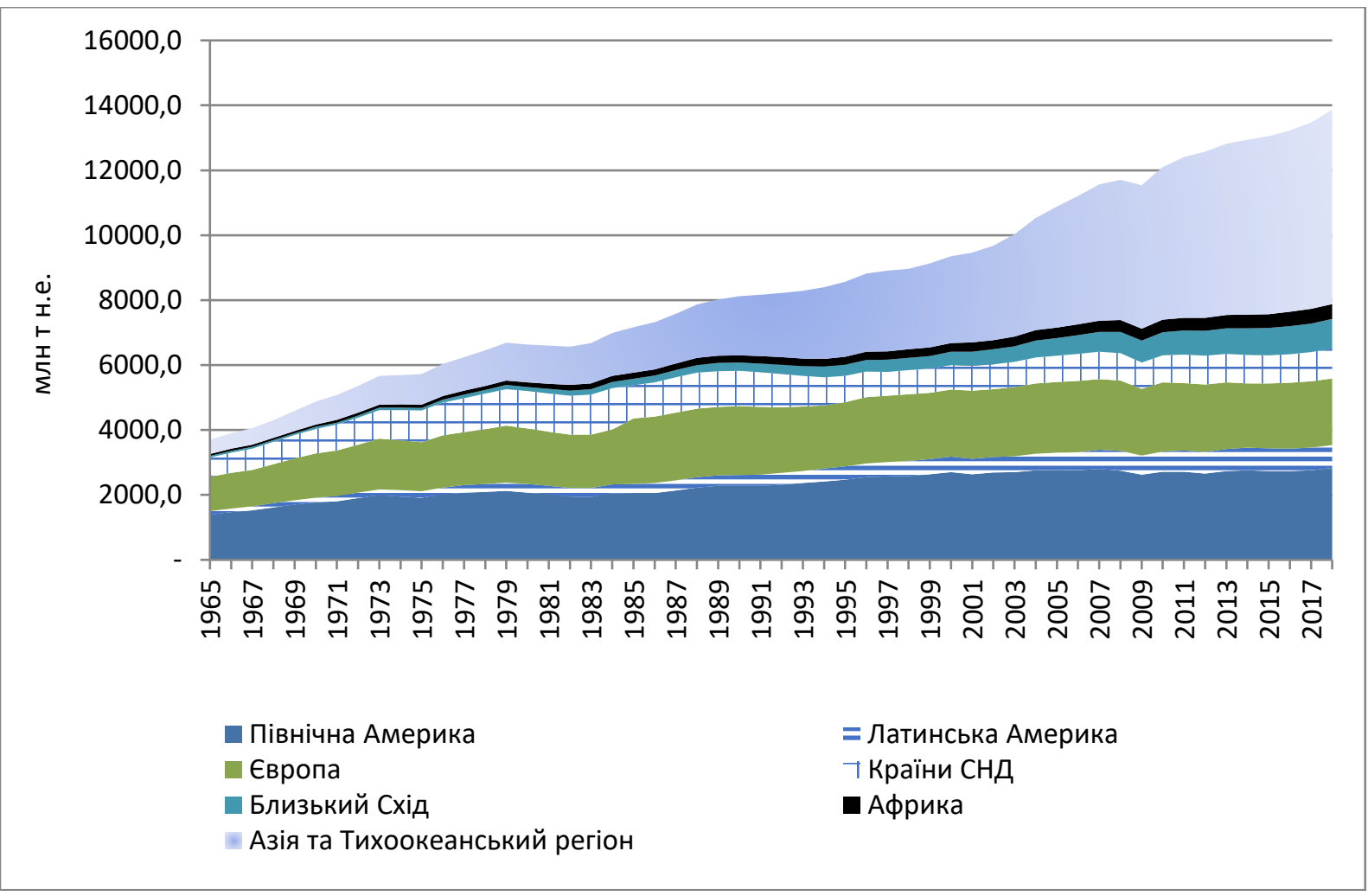

\section{Рисунок 2 - Споживання первинної енергії за регіонами світу у 1965-2018 рp.* *складено за даними BP Statistical Review of World Energy June 2019 [23]}

Так, помітне зростання споживання первинної енергії країнами АзійськоТихоокеанського регіону дозволило їм у 1993 році випередити за цим показником країни Європи, а у 2001 році - країни Північної Америки. Збільшення інтенсивності споживання 3 боку країн Азійсько-Тихоокеанського регіону, що відмічається з початку 2000-х років, забезпечило їм за теперішнього часу беззаперечні лідируючі позиції на ринку. При цьому спостерігається одночасне помірне скорочення питомої частки за обсягами споживання первинної енергії країн Північної Америки, Європи, країн СНД, при цьому абсолютні показники попиту з боку цих країн протягом останніх років суттєво не змінилися, демонструючи у відповідні періоди зростання або скорочення. Варто відзначити, що й за іншими регіонами світу, як то Латинська Америка, Близький Схід, Африка відмічалося протягом аналізованого періоду зростання попиту на первинну енергію, проте воно було настільки помірним, що у загальносвітовому масштабі дані країни не змінили своїх позицій у структурі споживання.

Отже, зміни у географічній структурі споживання первинної енергії за останні п’ятдесят років призвели до зміни лідерів за цим показником за регіонами світу. Так, якщо у 1965 році на країни Північної Америки припадало 37,6\% світового попиту на первинну енергію, на країни Європи - 28,6\%, СРСР - 16\%, країни АзійськоТихоокеанського регіону - 11,9\%, то вже у 2018 році країни Азійсько-Тихоокеанського регіону були беззаперечними лідерами та споживали 43,2\% первинної енергії у світі, на країни Північної Америки припадало 20,4\%, країни Свропи - 14,8\%, країни СНД - 6,7\%. 
Аналіз тенденцій споживання первинної енергії за останні п'ятдесят років за основними видами (рис. 3) показав, що зростання відмічається за всіма енергетичними ресурсами. Найбільш інтенсивно з 1965 року по 2018 рік збільшились обсяги споживання відтворювальної енергії (у більше ніж 136 разів) та атомної енергії (більше ніж у 105 разів). Споживання природного газу зросло у 6,1 рази, гідроенергії - у 4,6 рази, нафти у 3 рази, вугілля - у 2,7 рази. Подібні тенденції призвели до певних змін у структурі споживання первинних видів енергії. Так, якщо у 1965 році на нафту припадало 41,9\% світового споживання первинної енергії, на вугілля - 37,5\%, природний газ - 14,7\%, гідроенергію - 5,6\%, на атомну енергію - 0,2\%, відновлювальну енергію - 0,1\%, то у 2018 році на нафту вже припадало 33,6\% спожитої первинної енергії, на вугілля - 27,2\%, природний газ - 23,9\%, гідроенергію $-6,8 \%$, на атомну енергію $-4,4 \%$, відновлювальну енергію $-4 \%$.

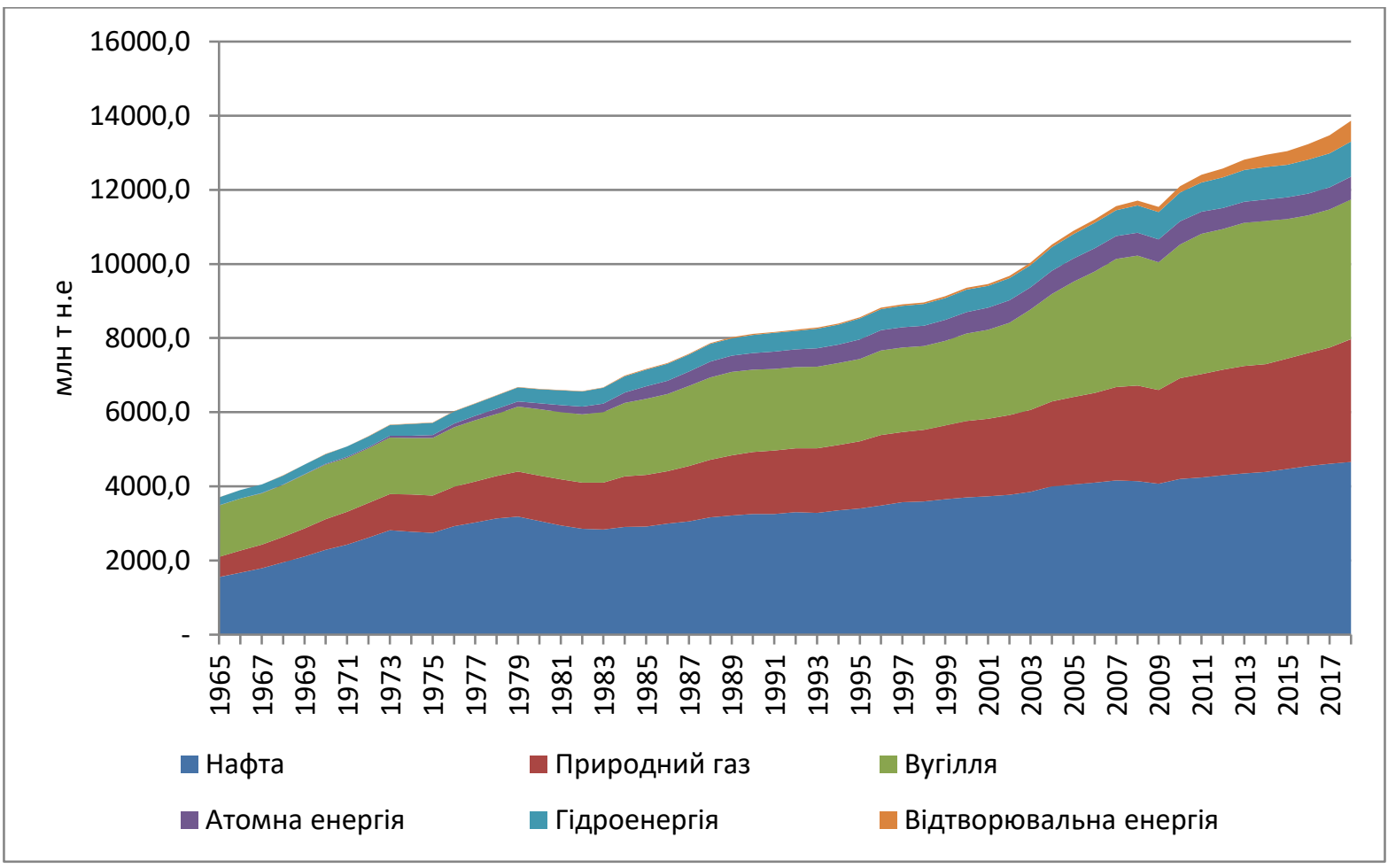

Рисунок 3 - Споживання первинної енергії за видами у 1965-2018 рр.*

*складено за даними BP Statistical Review of World Energy June 2018 [23]

На тлі зростання обсягів споживання первинної енергії у світі позитивною тенденцією останніх десятирічь $є$ зниження показника глобальної енергоємності, тобто загального споживання енергії на одиницю ВВП, що свідчить про підвищення енергетичної ефективності глобальної економіки. Як видно з рис. 4, у світі у цілому за двадцять вісім років помітно скоротилося значення показника енергоємності з 0,174 кг н.е. / \$2015 ВВП за ПКС у 1990 році до 0,114 кг н.е. / \$2015 ВВП за ПКС у 2018 році або на $34,5 \%$. У цілому скорочення показника спостерігалося протягом усього цього періоду, варіюючись за інтенсивністю у різні роки, за виключенням 2002, 2009 та 2010 років, коли енергоємність не змінювалась, залишаючись на попередньому рівні. 


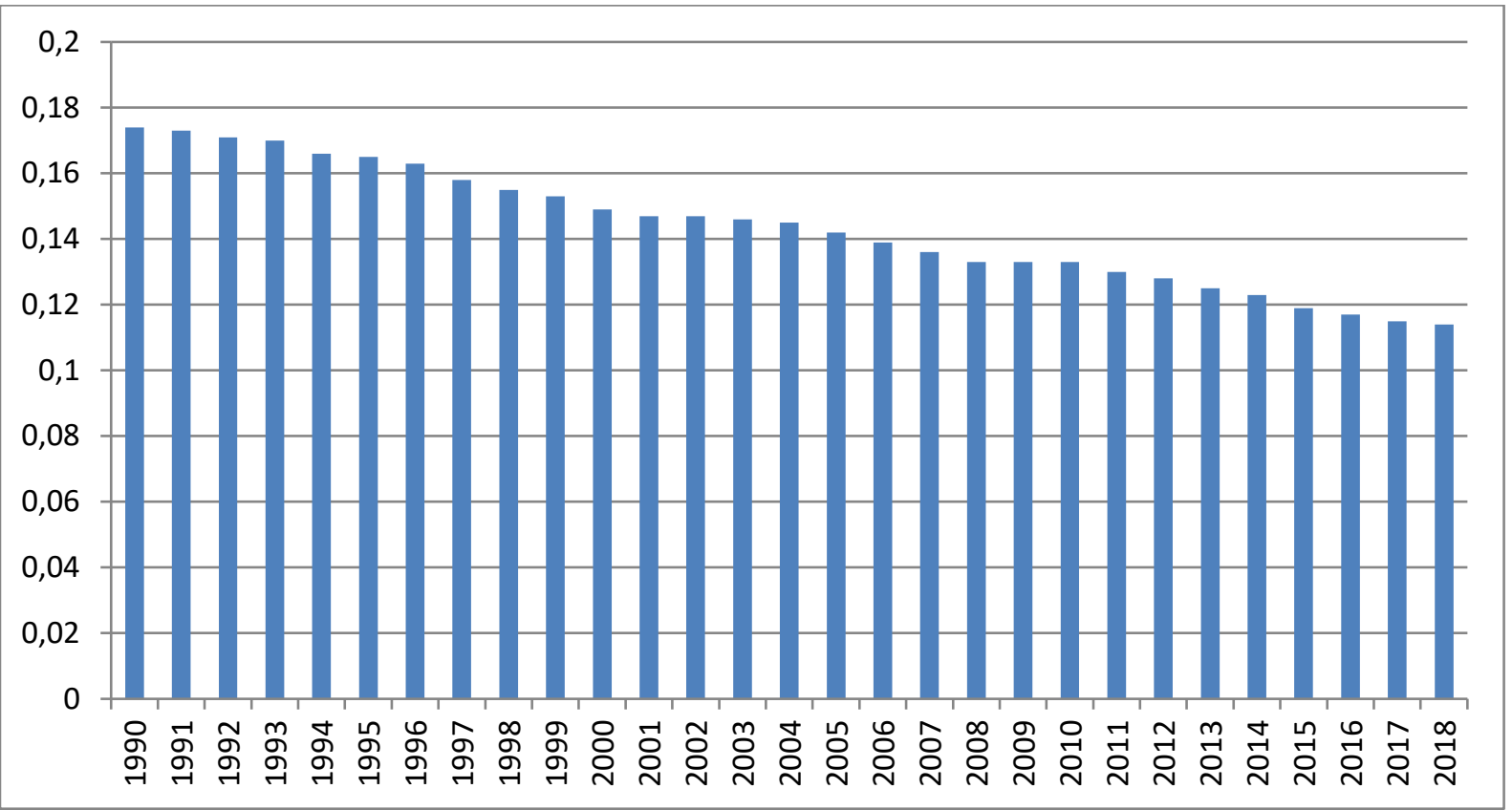

\section{Рисунок 4 - Динаміка глобальної енергоємності у 1990-2018 pp. (у кг н.е. /\$2015 ВВП за ПКС)* \\ *Складено за даними Міжнародної енергетичної агенції Enerdata [24]}

Останнім часом спостерігається уповільнення зниження даного показника. Так, якщо у 2015 році скорочення становило 3,3\%, у 2016 та 2017 роках воно дорівнювало $1,7 \%$, то у 2018 році - усього $0,9 \%$. Зниження глобальної енергоємності у 2018 році було нижче середньорічного скорочення у 1,6\%, яке спостерігалось у період з 2000 по 2018 роки. Це свідчить про деяке уповільнення зростання енергетичної ефективності глобальної економіки. Рівні та тенденції енергоємності суттєво різняться за регіонами світу, що свідчить про відмінності в економічній структурі та досягненнях у сфері енергоефективності. Енергоємність економіки США у 2018 році зросла на 0,6\% у порівнянні із 2017 роком, тоді як протягом 1990-2017 років іiі зменшення по країні у середньому становило $1,9 \%$ на рік. Поліпшення енергоефективності тривало в Європейському Союзі - регіоні з найнижчою енергоємністю у світі та з високим рівнем iï скорочення у 2018 році (на $3,1 \%$ ). Середній річний темп зниження у даному регіоні становив $1,8 \%$ у період 2000-2017 років [24].

Як видно 3 таблиці 1, протягом останніх п'яти років склад країн-лідерів за показником енергетичної ефективності економіки є відносно стабільним, лише дещо змінюються їх позиції у рейтингу. Перше місце весь цей період посідає Колумбія, яка характеризується найнижчим у світі рівнем енергоємності економіки, у 2018 році він становив 0,054 кг н.е. / \$2015 ВВП за ПКС, що майже у двічі нижче середньосвітового рівня. Всі країни-лідери протягом періоду демонструють помірне скорочення енергоємності, виключення складає Чилі, що обумовило зниження іiї позицій у рейтингу. Склад країн $з$ найвищими значеннями енергоємності економіки протягом 2014-2018 років був також відносно стабільним.

Протягом всіх років Україна характеризувалася найнижчими значеннями показника енергетичної ефективності у світі, у 2018 році показник енергоємності іiі економіки становив 0,238 кг н.е. / \$2015 ВВП за ПКС, що перевищує середньосвітовий рівень більше ніж у два рази. Позитивною тенденцією $є$ зниження рівня енергоємності 
економіки України протягом даних п'яти років на 15\%, у 2018 році у порівнянні 3 попереднім роком скорочення становило 4,8\%. Відносно рівня 1990 року енергоємність економіки України скоротилась більше ніж на 43\%, коли цей показник становив 0,420 кг н.е. / \$2015 ВВП за ПКС.

Протягом останніх п’яти років стабільне скорочення також демонстрували Узбекистан, Тайвань і Китай. Так, енергоємність Китаю покращилася майже на $40 \%$ за період з 2000 по 2018 роки і на 2,7\% за останній рік у результаті впровадження політики енергоефективності, орієнтованої на енергоємні галузі, що обумовило високий попит в країні на послуги з енергоефективності.

Рейтинг країн за показником енергетичної ефективності

Таблиця 1

\section{(у кг н.е. /\$2015 ВВП за ПКС)*}

\begin{tabular}{|c|c|c|c|c|c|c|c|c|c|c|}
\hline \multirow[b]{2}{*}{ Країна } & \multicolumn{2}{|c|}{2014 рік } & \multicolumn{2}{|c|}{2015 рік } & \multicolumn{2}{|c|}{2016 рік } & \multicolumn{2}{|c|}{2017 рік } & \multicolumn{2}{|c|}{2018 рік } \\
\hline & 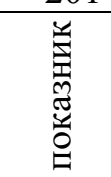 &.$\frac{\mathscr{U}}{\vec{z}}$ & 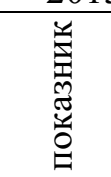 & . & 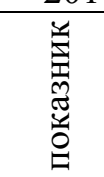 &.$\stackrel{0}{\Sigma}$ & 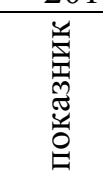 & $\stackrel{\circlearrowright}{\stackrel{0}{z}}$ & 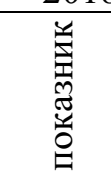 & $\stackrel{\mathscr{v}}{\vec{z}}$ \\
\hline \multicolumn{11}{|c|}{ Крайни з найвицими значеннями енергетичної ефективності } \\
\hline Колумбія & 0,060 & 1 & 0,058 & 1 & 0,059 & 1 & 0,055 & 1 & 0,054 & 1 \\
\hline Туреччина & 0,066 & 2 & 0,066 & 2 & 0,068 & 4 & 0,068 & 4 & 0,066 & 4 \\
\hline Італія & 0,067 & 3 & 0,069 & 4 & 0,067 & 3 & 0,067 & 3 & 0,067 & 5 \\
\hline Великобританія & 0,068 & 4 & 0,067 & 3 & 0,065 & 2 & 0,063 & 2 & 0,062 & 2 \\
\hline Португалія & 0,071 & 5 & 0,072 & 5 & 0,071 & 6 & 0,072 & 7 & 0,069 & 6 \\
\hline Іспанія & 0,073 & 6 & 0,074 & 6 & 0,072 & 7 & 0,072 & 6 & 0,070 & 7 \\
\hline Румунія & 0,077 & 7 & 0,075 & 7 & 0,071 & 5 & 0,068 & 5 & 0,065 & 3 \\
\hline Німеччина & 0,080 & 8 & 0,079 & 9 & 0,078 & 9 & 0,077 & 8 & 0,072 & 8 \\
\hline Сгипет & 0,083 & 9 & 0,079 & 8 & 0,082 & 11 & 0,081 & 10 & 0,078 & 10 \\
\hline Індонезія & 0,083 & 10 & 0,079 & 10 & 0,077 & 8 & 0,077 & 9 & 0,076 & 9 \\
\hline Японія & 0,086 & 11 & 0,084 & 11 & 0,082 & 10 & 0,081 & 11 & 0,079 & 11 \\
\hline Чилі & 0,088 & 12 & 0,088 & 13 & 0,092 & 16 & 0,092 & 17 & 0,092 & 18 \\
\hline Мексика & 0,090 & 13 & 0,087 & 12 & 0,085 & 12 & 0,084 & 12 & 0,080 & 12 \\
\hline \multicolumn{11}{|c|}{ Крайни з найниячими значеннями енергетичної ефективності } \\
\hline Україна & 0,280 & 1 & 0,273 & 1 & 0,271 & 1 & 0,250 & 1 & 0,238 & 1 \\
\hline Узбекистан & 0,248 & 2 & 0,205 & 3 & 0,183 & 6 & 0,176 & 6 & 0,176 & 6 \\
\hline Тайвань & 0,211 & 3 & 0,207 & 2 & 0,206 & 2 & 0,200 & 3 & 0,198 & 3 \\
\hline ПАР & 0,198 & 4 & 0,187 & 5 & 0,192 & 4 & 0,186 & 4 & 0,187 & 4 \\
\hline Росія & 0,195 & 5 & 0,196 & 4 & 0,203 & 3 & 0,211 & 2 & 0,215 & 2 \\
\hline Казахстан & 0,177 & 6 & 0,178 & 6 & 0,184 & 5 & 0,181 & 5 & 0,181 & 5 \\
\hline Канада & 0,177 & 7 & 0,175 & 7 & 0,173 & 7 & 0,174 & 7 & 0,176 & 7 \\
\hline Іран & 0,168 & 8 & 0,169 & 8 & 0,157 & 9 & 0,155 & 9 & 0,164 & 8 \\
\hline Китай & 0,160 & 9 & 0,151 & 10 & 0,140 & 10 & 0,135 & 12 & 0,131 & 12 \\
\hline Південна Корея & 0,158 & 10 & 0,158 & 9 & 0,159 & 8 & 0,158 & 8 & 0,157 & 9 \\
\hline Нігерія & 0,137 & 11 & 0,132 & 11 & 0,139 & 11 & 0,141 & 11 & 0,141 & 11 \\
\hline Саудівська Аравія & 0,130 & 12 & 0,130 & 12 & 0,121 & 14 & 0,124 & 13 & 0,119 & 13 \\
\hline Венесуела & 0,123 & 13 & 0,117 & 16 & 0,131 & 12 & 0,145 & 10 & 0,156 & 10 \\
\hline Coim & 0,123 & & 0,120 & & 0,117 & & 0,115 & & 0,114 & \\
\hline
\end{tabular}

*Складено за даними Міжнародної енергетичної агениіï Enerdata [24] 
По інших країнах 3 найвищим показником енергоємності спостерігається періодичне як скорочення, так і зростання показника, виключення становить Російська Федерація, для якої характерне стабільне зростання у цей період енергоємності економіки. Енергоємність у країнах СНД постійно зменшується - 32000 року у середньому на 2,7\% на рік, але залишається найвищою у світі - на 75\% вище середнього рівня по світу. Висока енергоємність в Україні, у країнах СНД, на Близькому Сході, в Китаї та інших азійських країнах, що розвиваються, пояснюється домінуванням енергоємних галузей промисловості, економікою, орієнтованою на експорт товарів, i низькими цінами на енергоресурси, що не сприяють енергоефективності [24].

Активне використання енергії для задоволення потреб зростаючої економіки у другій половині 20 -го сторіччя спричинило збільшення викидів двоокису вуглецю $\left(\mathrm{CO}_{2}\right)$ та, відповідно, виникнення низки екологічний проблем. У цілому по світу з 1965 року по 2018 рік обсяг викидів збільшився більше ніж у три рази та має тенденцію до зростання. Після трьохрічної стагнації викидів до 2016 року, пов'язаної зі слабким економічним зростанням, зниженням енергоємності та зміною у структурі споживання палива, викиди $\mathrm{CO}^{2}$ зросли на $1 \%$ у 2017 році та на $1,9 \%$ у 2018 році відносно попереднього року. Як видно 3 рисунку 5, з початку 2000-х років нарощування викидів стало інтенсивніше, причому, це відбувається за рахунок країн, які не входять до ОЕСР. Ці країни з 1965 року по 2018 рік збільшили обсяг викидів більше ніж у шість разів. Причому з 1965 по 2004 роки зростання спостерігалося у 3,3 рази, тоді як тільки з 2004 по 2018 роки зростання зафіксовано у 1,9 рази, що свідчить про суттєву інтенсифікую даного процесу. 32004 року та по теперішній час країни, що не входять до ОЕСР, є основними забруднювачами двоокисом вуглецю у світі, на їх частку у 2018 році припадає 63,4\% від загального обсягу викидів. У той час, як по країнах-членах ОЕСР, у тому числі й по країнах $\mathrm{CC}$, останніми роками спостерігається скорочення викидів. При цьому, країни, що входять до ОЕСР, у 2018 здійснювали викиди $\mathrm{CO}^{2}$ на $60 \%$ більше, ніж у 1965 році, а країни $Є С$ - на 5\%.

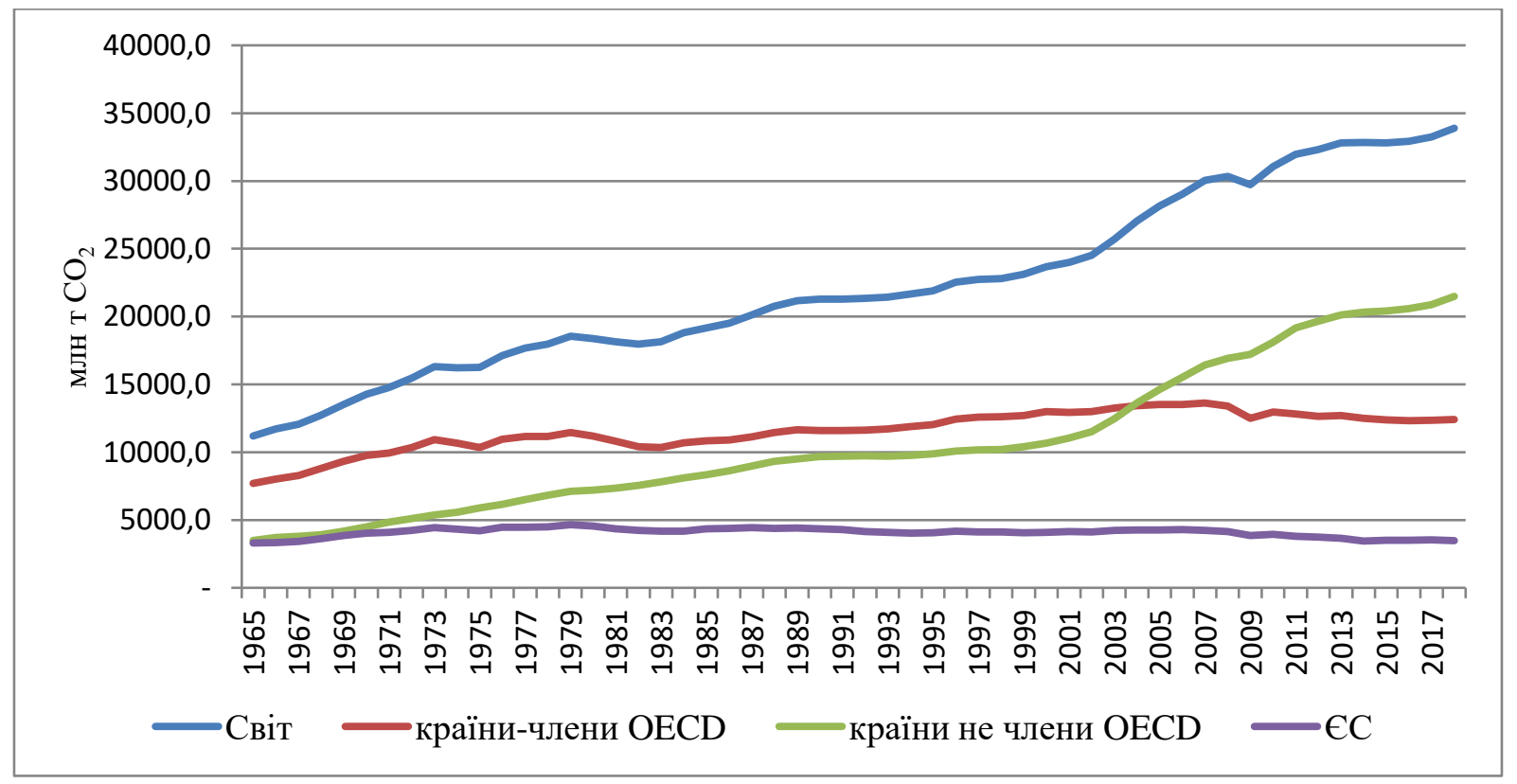

Рисунок 5 - Динаміка емісії двоокису вуглецю (CO2) у світі у 1965-2018 рр.*

*складено за даними BP Statistical Review of World Energy June 2018 [23]

Як свідчать дані рис. 6, за країнами Північної Америки, Європи та колишнього Радянського Союзу у цілому протягом періоду спостерігається помірне скорочення 
викидів двоокису вуглецю, за іншими регіонами світу відмічається зростання даного показника, причому вельми інтенсивно даний процес протікає у країнах Азії та Тихоокеанського регіону, особливо починаючи з 2000-х років.

Хоча у 2018 році практично всі регіони характеризуються зростанням викидів $\mathrm{CO}^{2}$, окрім Європи та Латинської Америки. Зростання викидів у Китаї у 2018 порівняно з 2017 роком становило $3,1 \%$, незважаючи на політику переходу з вугілля на газ, в Індії - 4,2\% та у Російській Федерації - 3,9\%. Викиди $\mathrm{CO}^{2}$ у Сполучених Штатах Америки зросли на $3,1 \%$ за рахунок збільшення споживання енергії, частково обумовленому погодними умовами. Викиди $\mathrm{CO}^{2}$ скоротилися у Свропейському Союзі $(-2,1 \%)$ через зменшення попиту на енергію (наприклад, у Німеччині), більшого внеску відновлюваних джерел енергії у виробництво електроенергії та погодних умов. У Японії викиди $\mathrm{CO}^{2}$ продовжували зменшуватися п'ять років поспіль завдяки зростаючому внеску сонячної енергії з 2016 року та збільшенню генерації ядерної енергії у 2018 році [25]. В Україні у 2018 році обсяг викидів $\mathrm{CO}^{2}$ становив 186,5 млн т $\mathrm{CO}^{2}$, що у 2,8 рази нижче рівня 1984 року, найменше значення за період відмічено у 2017 році - 185 млн т $\mathrm{CO}^{2}$ [23].

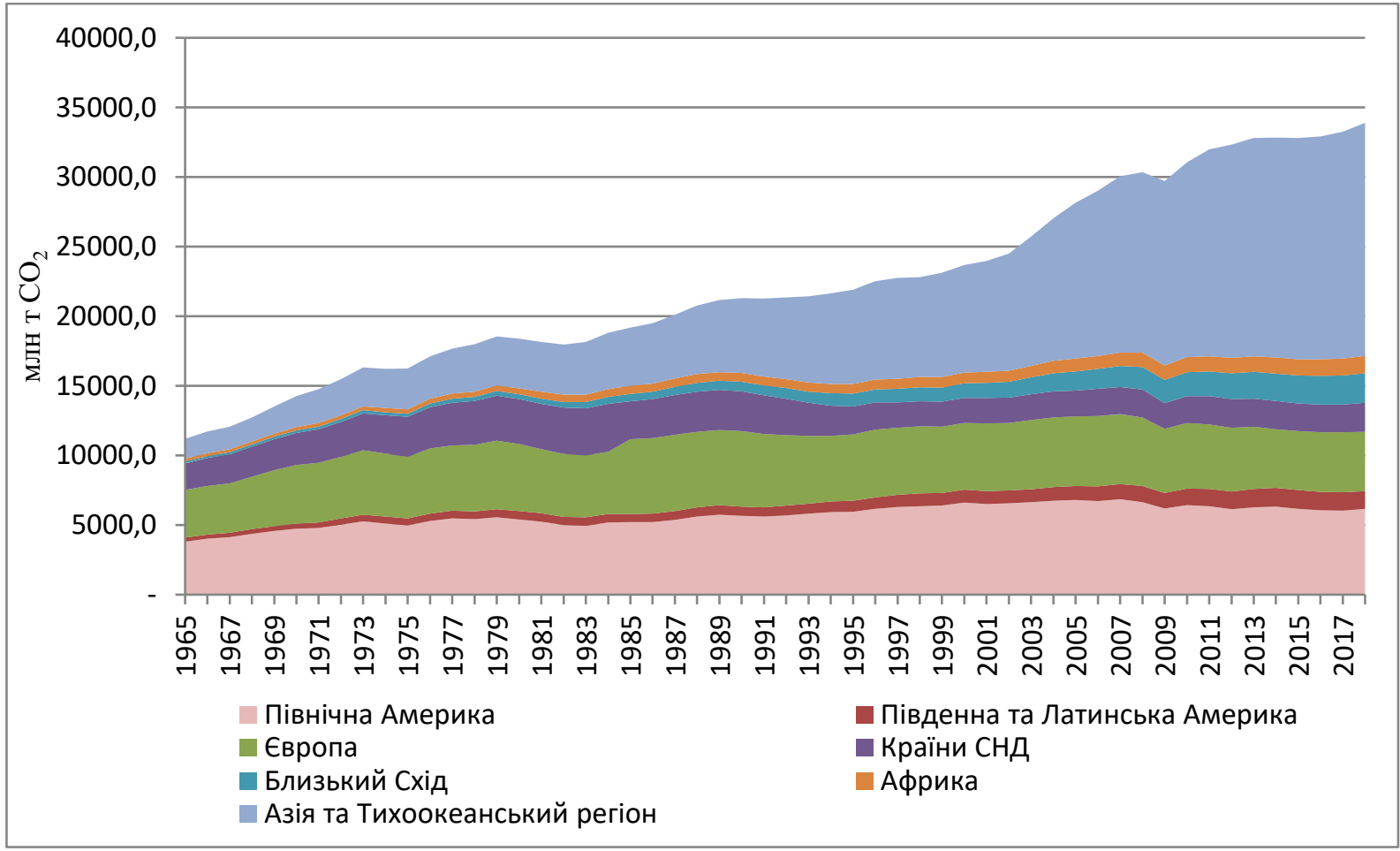

Рисунок 6 - Динаміка емісії двоокису вуглецю $\left(\mathrm{CO}_{2}\right)$ за регіонами світу y 1965-2018 pp.*

*складено за даними BP Statistical Review of World Energy June 2018 [23]

Інтенсивність викидів двоокису вуглецю у розрахунку на одиницю ВВП у світі протягом останніх десятирічь поступово знижується, про що свідчать дані рисунку 7, за виключенням декількох періодів, коли спостерігалося незначне зростання - у 2003 та 2010 роках. У 2018 році даний показник по світу дорівнював 0,26 кг $\mathrm{CO}_{2} / 1$ \$ ВВП, що на 35,6\% менше показника 1990 року, коли він становив 0,404 кг $\mathrm{CO}_{2} / 1$ \$ ВВП. 


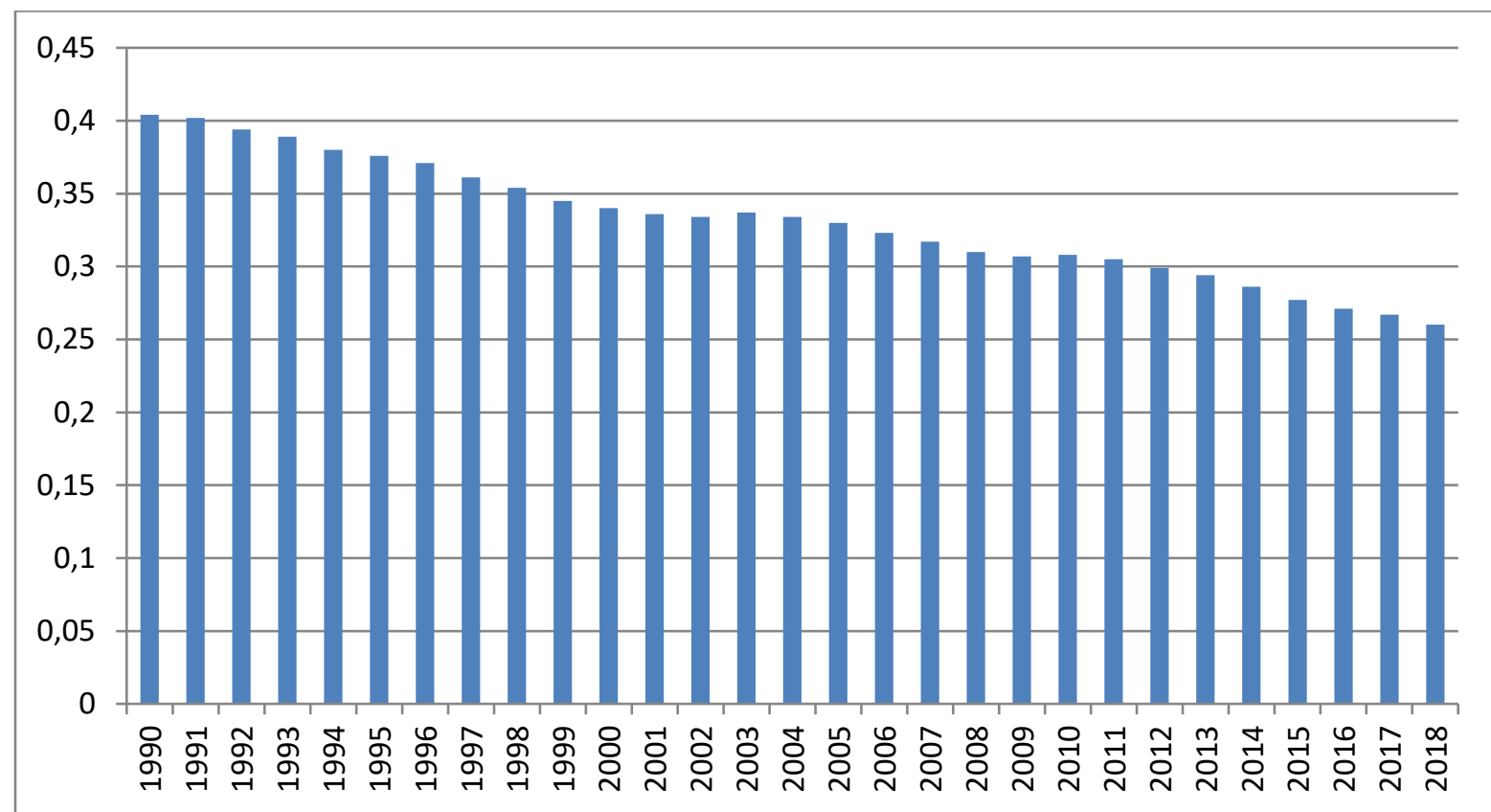

Рисунок 7 - Динаміка інтенсивності викидів двоокису вуглецю на одиницю ВВП у світі у 1990-2018 pp. (у кг СО2/\$2015 ВВП за ПКС)*

*Складено за даними Міжнародної енергетичної агенції Enerdata [26]

Протягом періоду відмічається уповільнення зниження світової інтенсивності викидів $\mathrm{CO}^{2}$ у розрахунку на одиницю ВВП. У 2018 році інтенсивність викидів $\mathrm{CO}^{2}$ у розрахунку на одиницю ВВП у середньому по світу знизилася на 2,6\%, що свідчить про прогрес порівняно із середнім показником скорочення за 2000-2017 рр., яке становило $1,5 \%$ на рік, проте цього все одно недостатньо, щоб відповідати цілям Паризької угоди. Зв'язок між викидами та економікою вказує на те, що розширення світової економіки переважало над збільшенням викидів. Інтенсивність викидів $\mathrm{CO}^{2}$ у розрахунку на одиницю ВВП зменшилася у великих країнах-забруднювачах, таких як Китай та Індія, що вказує на можливість зниження залежності від інтенсивних $\mathrm{CO}^{2}$ процесів. У Європейському Союзі - регіоні з найменшим вмістом $\mathrm{CO}^{2}$ у розрахунку на одиницю ВВП у світі - у 2018 році спостерігається зменшення даного показника на 4,2\%, спричинене зниженням викидів у більшості країн-членів $\mathcal{C}$, таких як Франція, Німеччина та Великобританія [26]. Проте, інтенсивність $\mathrm{CO}^{2}$ у розрахунку на одиницю ВВП незначно зросла у 2018 році в Північній Америці (+ 0,2\%) і суттєво збільшилась у Російській Федерації (+ 2,1\%) та в Африці (близько + 3\% в Алжирі та Нігеріï).

Аналіз країн за показником інтенсивності викидів двоокису вуглецю у розрахунку на одиницю ВВП дозволив визначити країни з найбільшими та найменшими значеннями даного показника (табл. 2). Зростання значення даного показника у Нігерії у 2017 та 2018 році позбавив дану країну статусу лідера серед країн з найнижчою інтенсивністю викидів. До першої п’ятірки протягом періоду 2014-2018 роки також входили Швеція, Франція, Норвегія та Колумбія.

Перелік країн з найвищими значеннями показника інтенсивності викидів двоокису вуглецю у розрахунку на одиницю ВВП також $є$ відносно стабільним. До їх числа входять ПАР, Україна, Узбекистан, Казахстан, Російська Федерація, Тайвань, Китай та інші. Для всіх них характерне активне використання вугілля як джерела первинної енергії. 
Рейтинг країн за інтенсивністю викидів діоксину вуглецю на одиницю ВВП (у кг СО2/\$2015 ВВП за ПКС)*

\begin{tabular}{|c|c|c|c|c|c|c|c|c|c|c|}
\hline \multirow[b]{2}{*}{ Країна } & \multicolumn{2}{|c|}{2014 рік } & \multicolumn{2}{|c|}{2015 рік } & \multicolumn{2}{|c|}{2016 рік } & \multicolumn{2}{|c|}{2017 рік } & \multicolumn{2}{|c|}{2018 рік } \\
\hline & 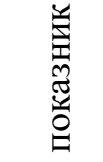 & . & 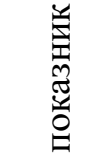 & $\cdot \stackrel{\mathscr{v}}{\Sigma}$ & 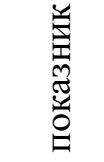 & . & 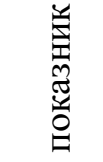 & $\cdot \stackrel{\mathscr{U}}{\Sigma}$ & 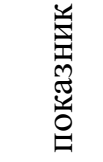 &.$\frac{\mathscr{J}}{2}$ \\
\hline \multicolumn{11}{|c|}{ Країни з найнижчими значеннями показника } \\
\hline Нігерія & 0,085 & 1 & 0,078 & 1 & 0,082 & 1 & 0,087 & 2 & 0,090 & 2 \\
\hline Швеція & 0,087 & 2 & 0,082 & 2 & 0,082 & 2 & 0,078 & 1 & 0,077 & 1 \\
\hline Франція & 0,114 & 3 & 0,115 & 3 & 0,113 & 3 & 0,112 & 4 & 0,106 & 3 \\
\hline Норвегія & 0,120 & 4 & 0,119 & 5 & 0,115 & 4 & 0,124 & 5 & 0,114 & 5 \\
\hline Колумбія & 0,122 & 5 & 0,118 & 4 & 0,127 & 5 & 0,107 & 3 & 0,107 & 4 \\
\hline Бразилія & 0,145 & 6 & 0,143 & 6 & 0,138 & 7 & 0,137 & 7 & 0,132 & 7 \\
\hline Португалія & 0,147 & 7 & 0,158 & 10 & 0,156 & 12 & 0,165 & 12 & 0,154 & 11 \\
\hline Італія & 0,149 & 8 & 0,151 & 8 & 0,148 & 9 & 0,144 & 8 & 0,142 & 9 \\
\hline Іспанія & 0,151 & 9 & 0,156 & 9 & 0,145 & 8 & 0,152 & 10 & 0,144 & 10 \\
\hline Великобританія & 0,158 & 10 & 0,148 & 7 & 0,137 & 6 & 0,132 & 6 & 0,127 & 6 \\
\hline Румунія & 0,168 & 11 & 0,162 & 11 & 0,152 & 10 & 0,151 & 9 & 0,138 & 8 \\
\hline Туреччина & 0,171 & 12 & 0,168 & 13 & 0,173 & 13 & 0,175 & 13 & 0,173 & 14 \\
\hline Індонезія & 0,172 & 14 & 0,163 & 12 & 0,163 & 11 & 0,158 & 11 & 0,158 & 12 \\
\hline \multicolumn{11}{|c|}{ Країни з найвищими значеннями показника } \\
\hline ПАР & 0,616 & 1 & 0,574 & 1 & 0,585 & 2 & 0,568 & 1 & 0,574 & 1 \\
\hline Україна & 0,613 & 2 & 0,562 & 2 & 0,580 & 1 & 0,494 & 4 & 0,473 & 4 \\
\hline Узбекистан & 0,571 & 3 & 0,575 & 5 & 0,425 & 7 & 0,407 & 6 & 0,406 & 6 \\
\hline Казахстан & 0,542 & 4 & 0,519 & 3 & 0,524 & 3 & 0,517 & 2 & 0,515 & 2 \\
\hline Тайвань & 0,509 & 5 & 0,506 & 4 & 0,508 & 4 & 0,513 & 3 & 0,500 & 3 \\
\hline Китай & 0,490 & 6 & 0,457 & 6 & 0,426 & 6 & 0,406 & 7 & 0,393 & 7 \\
\hline $\begin{array}{l}\text { Російська } \\
\text { Федерація }\end{array}$ & 0,430 & 7 & 0,444 & 7 & 0,439 & 5 & 0,461 & 5 & 0,471 & 5 \\
\hline Іран & 0,413 & 8 & 0,415 & 8 & 0,373 & 8 & 0,369 & 8 & 0,391 & 8 \\
\hline Австралія & 0,358 & 9 & 0,351 & 10 & 0,354 & 10 & 0,346 & 11 & 0,338 & 12 \\
\hline Південна Корея & 0,357 & 10 & 0,356 & 9 & 0,355 & 9 & 0,359 & 9 & 0,360 & 9 \\
\hline Канада & 0,355 & 11 & 0,351 & 11 & 0,349 & 11 & 0,348 & 10 & 0,349 & 10 \\
\hline Саудівська Аравія & 0,320 & 12 & 0,323 & 12 & 0,315 & 12 & 0,320 & 12 & 0,305 & 13 \\
\hline Венесуела & 0,277 & 14 & 0,274 & 14 & 0,297 & 13 & 0,319 & 13 & 0,341 & 11 \\
\hline Світ & 0,286 & & 0,277 & & 0,271 & & 0,267 & & 0,260 & \\
\hline
\end{tabular}

*Складено за даними Міжнародної енергетичної агениії Enerdata [26]

Україна, нажаль, відрізняється одними з найвищих значень показника у світі. У 2014-2015 рр.. вона була другою у рейтингу, у 2016 р. посіла 1 місце із значенням показника 0,580 кг $\mathrm{CO}_{2} / 1$ \$ ВВП, у той час як світовий показник у цей період дорівнював 0,271 кг $\mathrm{CO}_{2} / 1$ \$ ВВП. Скорочення значень у наступні роки дозволило Україні опуститися на 4 позицію. У 2018 році вона мала найнижче значення даного показника за п’ять останніх років - 0,473 кг $\mathrm{CO}_{2}$ / 1 \$ ВВП, що свідчить про певні позитивні зрушення, проте все одно провідною проблемою вітчизняної економіки лишаються значна енергоємність виробництва, вкрай неефективне використання енергетичних ресурсів, застарілість і недостатність використовуваних технологій виробництва та очищення викидів. 
Висновки. Проведений аналіз глобальних енергетичних та екологічних тенденцій дозволяє зробити низку висновків та узагальнень. Споживання первинної енергії у світі за останні п'ятдесят років безупинно зростає, за виключенням періоду фінансовоекономічної кризи 2008 року. У географічній структурі світового споживання первинної енергії за цей період відбулися помітні зміни. 3 кінця минулого сторіччя лідируючі позиції починають займати країни Азійсько-Тихоокеанського регіону, причому останні два десятиріччя їх питома частка інтенсивно збільшується. Задоволення зростаючого попиту на первинну енергію більшою мірою забезпечується за рахунок зростання обсягів споживання вугілля, нафти та газу. Незважаючи на інтенсивне зростання обсягу відтворювальної первинної енергії у структурі споживання за теперішнього часу іiі питома частка незначна та найближчим часом суттєво не збільшиться. Енергетична ефективність глобальної економіки має позитивну тенденцію до зростання, проте інтенсивне споживання вугілля, нафти та газу з метою забезпечення зростаючого попиту на енергію сприяє збільшенню навантаження на навколишнє природне середовище шляхом зростання викидів двоокису вуглецю. Ця тенденція відмічається помітним випереджанням тенденції впровадження відновлювальної енергетики, що спричинятиме помітні екологічні наслідки. Вищезазначене свідчить про необхідність більш масштабного та комплексного підходу до застосування інструментів екологічної політики на всіх рівнях управління, більш активного впровадження природоохоронних та ресурсозберігаючих заходів для попередження тих негативних наслідків, незворотність яких з кожним днем стає все більш неминучою.

\section{СПИСОК ВИКОРИСТАНИХ ДЖЕРЕЛ}

1. Власенко В. О. Екологічна економіка як інструмент упровадження сталого розвитку: поняття та принципи правового регулювання. Зовнішня торгівля: економіка, фінанси, право. 2013. № 5-6. C. 22-28. URL: http://nbuv.gov.ua/UJRN/-uazt_2013_5-6_6.

2. Герасимчук 3.В. Еколого-економічні основи формування та реалізації регіональної політики сталого розвитку (питання методології та методики): Автореф. дис. ... доктора екон. наук: 08.10.01 / Ін-т регіональних досліджень. НАНУ. Львів, 2002. 47 с.

3. Гринів Л.С. Екологічно збалансована економіка: проблеми теорії: монографія. Львів: ЛНУ ім. І. Франка, 2001. 240 с

4. Грищенко В.Ф. Экологизация международных отношений в условиях глобализации. Вісник Сумського державного університету. Серія. Економіка. 2005. №2(74). С. 36-42.

5. Данилишин Б.М. Эколого-экономические проблемы обеспечения устойчивого развития производительных сил Украины (на примере АПК Украины): Дис. ... доктора екон. наук: 08.10.01 / НАН Украины; Совет по изучению производительных сил Украины, 1997. 398 с.

6. Дергачова В.В. Енергоекономічні чинники сталого розвитку: аналіз та оцінка впливу: Автореф. дис. ... канд. екон. наук: 08.02.03 /Інститут економічного прогнозування. НАНУ. К., 2001. 19 с.

7. Дорогунцов С.И., Ральчук А.И. Управление техногенно-экологической безопасностью в контексте парадигмы устойчивого развития: концепция системнодинамического решения. - К.: Наукова думка, 2002. - 201 с.

8. Жихарєва А.Б. Розвиток екологізації державного управління в Україні: монографія. К.: АМУ, 2017. 196 c.

9. Корпан Р.В. Екологізація управління та економічне зростання: моделювання та аналіз взаємозв'язку: Автореф. дис. ... канд. екон. наук: 08.08.01 / Сумський державний університет. Суми, 2005. 24 с. 
10. Кульчицький Я.В. Сучасні економічні системи в умовах екологізації та глобалізації (теоретико-методологічні засади порівняння): монографія. Львів: Ліга-Прес, 2011. 687 с. 11. Туниця Т.Ю. Міжнародні аспекти проблем екологізації економіки. Науковий вісник НЛТУ України. 2005. Вип. 15.6. С. 238-242.

12. Цибуляк А. Екологізація економіки України в умовах розширення співпраці з СС. Причорноморські економічні студії. 2016. Вип. 8. С. 31-35.

13. Gowdy J., O'Hara S. Economic theory for environmentalists. St. Lucie, Florida, 1996.

14. Common M. Environmental and Resource Economics: an Introduction. Edinburg (England), 1996.

15. Gandhi Ved P. (ed.). Macroeconomics and the Environment. Washington, 1996.

16. Keijzers G. The evolution of Dutch environmental policy: the changing ecological arena from 1970-2000 and beyond. Journal of Cleaner Production. 2000 (8). P. 179-2000.

17. Kohlstad C. D. Environmental Economics. New York, London, 2000.

18. Krarup S., Ramesohl S. Voluntary agreements on energy efficiency in industry - not a golden key, but another contribution to improve climate policy mix. Journal of Cleaner Production. 2002 (10). P. 109-120.

19. Hanks J. Voluntary agreements, climate change and industrial energy efficiency. Journal of Cleaner Production. 2002. №10. P. 103-107.

20. Hanley N., Shogren J., White B. Environmental economics in theory and practice. London, 1997.

21. The Prize in Economic Sciences 2018 URL: https://old.nobelprize.org/ecopress.pdf?_ga=2.151663408.843139967. 1538992785-9774466196.1538476224 - Title of the screen.

22. William D. Nordhaus, Zili Yang. A Regional Dynamic General-Equilibrium Model of Alternative Climate-Change Strategies. American Economic Review. Vol. 86, No. 4, September 1996 , pp.

741-765.

URL: http://www.econ.yale.edu/ nordhaus/homepage/homepage/cowles\%20foundation\%20paper\% $20 \% 23 \% 20930 . p d f$

23. BP Statistical Review of World Energy June 2019. URL: https://www.bp.com/en/global/corporate/energy-economics/statistical-review-of-worldenergy.html

24. Energy intensity (koe/\$2015p). Global Energy Statistical Yearbook 2019. URL: https://yearbook.enerdata.net/total-energy/world-energy-intensity-gdp-data.html - Title of the screen.

25. CO2 emissions from fuel combustion (MtCO2). Global Energy Statistical Yearbook 2019. URL: https://yearbook.enerdata.net/co2-fuel-combustion/world-CO2-intensity.html - Title of the screen.

26. CO2 intensity (kCO2/\$2015p). Global Energy Statistical Yearbook 2019. URL: https://yearbook.enerdata.net/co2-fuel-combustion/world-CO2-intensity.html - Title of the screen. 